\title{
Antimicrobial activity of doripenem against Gram-negative pathogens: results from INVITA-A-DORI Brazilian Study
}

\begin{abstract}
In vitro activity of doripenem and comparator antimicrobial agents was evaluated against Gram-negative bacilli recently isolated from Brazilian private hospitals that were enrolled in the INVITA-A-DORI Brazilian Study. A total of 805 unique Gram-negative bacilli were collected from patients hospitalized at 18 medical centers between May/08 and March/09. Each hospital was asked to submit 50 single Gram-negative bacilli isolated from blood, lower respiratory tract or intraabdominal secretions. Bacterial identification was confirmed and antimicrobial susceptibility testing was performed using Clinical Laboratory Standards Institute (CLSI) microdilution method at a central laboratory. CLSI M100-S21 (2011) or US-FDA package insert criteria (tigecycline) was used for interpretation of the antimicrobial susceptibility results. Doripenem was as active as meropenem and more active than imipenem against E. coli and K. pneumoniae isolates. A total of $50.0 \%$ of Enterobacter spp. isolates were resistant to ceftazidime but $85.7 \%$ of them were inhibited at doripenem MICs $\leq 1 \mu \mathrm{g} / \mathrm{mL}$. Polymyxin B was the only agent to show potent activity against Acinetobacter spp. $\left(\mathrm{MIC}_{50 / 90}, \leq 0.5 / 1 \mu \mathrm{g} / \mathrm{mL}\right)$ and P. aeruginosa $\left(\mathrm{MIC}_{50 / 90}, 1 / 2 \mu \mathrm{g} / \mathrm{mL}\right)$. Although high rates of imipenem (53.1\%) and meropenem (44.5\%) resistance were detected among P. aeruginosa, doripenem showed $\mathrm{MIC}_{50}$ of $16 \mu \mathrm{g} / \mathrm{mL}$ against imipenem-resistant $P$. aeruginos $a$ and inhibited a greater number of imipenem-resistant $P$. aeruginosa (10.5\%) at MIC values of $\leq 4 \mu \mathrm{g} / \mathrm{mL}$ than $\mathrm{did}$ meropenem $(0.0 \%)$. In this study, doripenem showed similar in vitro activity to that of meropenem and retained some activity against imipenem-resistant $P$. aeruginosa isolated from Brazilian medical centers.
\end{abstract}

Keywords: carbapenems; Gram-negative bacteria; Brazil.

\section{INTRODUCTION}

Doripenem is a novel parenteral $1-\beta$-methylcarbapenem with broad-spectrum activity against commonly isolated Gram-negative and Gram-positive pathogens. ${ }^{1,2}$ Doripenem, like meropenem and ertapenem, is stable to renal dehydropeptidase- 1 hydrolysis because of the presence of a 1- $\beta$-methyl constituent on the carbapenem nucleus. It also has a sulfamoylami noethyl-pyrrolidinylthio group in its side chain at position 2 that enhances its activity against non-fermentative Gram-negative bacilli. ${ }^{1,2}$ Doripenem acts by inactivating multiple essential penicillin binding proteins (PBPs) for cell wall biosynthesis resulting in subsequent cell death. It has high affinity for PBP1, PBP2, and PBP4 of Staphylococcus aureus as well as for PBP2, PBP3 and PBP4 of Escherichia coli and Pseudomonas aeruginosa. The binding affinity of doripenem for PBP2 of $P$. aeruginosa was stronger than that documented for most cephalosporins. ${ }^{3,4}$ In general, doripenem is less potent than imipenem, but more potent than meropenem, against Gram-positive bacteria. Against Gram-negative bacteria, the activity of doripenem is similar to that of meropenem but superior to that of imipenem. ${ }^{1,5,6}$ None of the clinically available carbapenems are effective against $E$. faecium, methicilin-resistant $S$. aureus or coagulase-negative staphylococci due to poor binding affinity to PBP5 and PBP2a, respectively. ${ }^{5,6}$ Doripenem is stable to hydrolysis by most $\beta$-lactamases, including penicillinases and cephalosporinases produced by Gram-positive and Gram-negative bacteria, but not to carbapenem hydrolyzing $\beta$-lactamases. ${ }^{1,4,7}$ Thus, doripenem like other carbapenems is not active against Stenotrophomonas maltophilia as a result of its intrinsic metallo- $\beta$-lactamase production., ${ }^{1,7}$

The favorable spectrum, potency and pharmacokinetics for doripenem have led to successful clinical trial results for intra-abdominal
Authors

Ana Cristina Gales

Heber D. Azevedo ${ }^{2}$

Rosângela Ferraz Cereda ${ }^{3}$

Raquel Girardello ${ }^{4}$

Danilo Elias Xavier

INVITA-A-DORI Brazilian Study Group ${ }^{6}$

${ }^{1} \mathrm{PhD}$ in Medicine; Associate Professor of Infectious Diseases,

Escola Paulista de Medicina-

Universidade Federal de São Paulo

(EPM-UNIFESP), SP, Brazil

${ }^{2} \mathrm{MD}$, Infectologist; Medical

Manager, Janssen-Cilag, Brazil

${ }^{3} \mathrm{PhD}$ in Medicine; Manager,

Latin America, Jassen-Cilag,

Brazil

${ }^{4}$ Biologist, PhD Student in

Sciences, EPM-UNIFESP, SP,

Brazil

${ }^{5}$ Pharmacist, $\mathrm{PhD}$ Student in

Sciences, EPM-UNIFESP, SP,

Brazil

${ }^{6}$ Marinês D.V. Martino, SP

Maria Beatriz G. de S. Dias, SP

Antonio Carlos C. Pignatari, SP

Guilherme Henrique Furtado,

SP; Marco Antonio Cyrillo, SP;

Gilberto Turcato Júnior, SP;

Cristina Mamedio, SP; Ana

Paula Volpato, SP; Ronaldo

Rozenbaum, RJ; Tatiana Pacheco

Campos, RJ; Danielle Provençano

Borghi, RJ; Silvana de Barros

Ricardo, MG; Maria Eugênia V.

Didier, MG; Silvana V. Superti, RS;

Gabriel Azambuja Narvaes, RS;

Rodrigo Duarte Perez, SC; Clóvis

Arns da Cunha, PR; Rosangela

Cipriano de Souza, MA; Antonio

Carlos Bandeira, BA

Submitted on: 01/31/2011 Approved on: 04/11/2011

Correspondence to:

Ana Cristina Gales

Rua Leandro Dupret, 188

04025-010

São Paulo, SP, Brazil

Phone/Fax:

+ 55-11-5081-2965

ana.gales@gmail.com

Financial Support: This

study was supported by an educational/research grant

from Janssen-Cilag.

Conflict of interest: ACG has received research funding and/or consultation fees from Janssen-Cilag,

Pfizer, Novartis, and SanofiAventis. Other authors have nothing to declare.

(ㅇ)2011 Elsevier Editora Ltda. All rights reserved. 
infections, nosocomial pneumonias, and complicated urinary tract infections. ${ }^{8}$ In October 2007, the doripenem clinical use was approved by the United States Food and Drug Administration (US-FDA) for treatment of complicated urinary tract and intra-abdominal infections. ${ }^{8}$ In Europe it is also licensed for treatment of nosocomial pneumonia, including ventilator-associated pneumonia.

In general, high resistance rates among key nosocomial pathogens have been reported in Brazil. ${ }^{9}$ However, most of these reports originates from surveillance programs that have evaluated isolates collected from a few public/ teaching hospitals. ${ }^{10}$ Local surveillance studies are of crucial importance to establish the role that a new antimicrobial agent might play in a geographic region since local variations in the frequency distribution of pathogens and antimicrobial susceptibility profiles have been reported. Although doripenem has been tested in vitro against clinical isolates collected worldwide, it has been not tested against a large collection of pathogens isolated from distinct Brazilian medical centers. The main objective of this study was to evaluate the in vitro activity of doripenem and comparator agents against Gram-negative bacilli recently isolated from Brazilian private hospitals.

\section{MATERIAL AND METHODS}

\section{Participant medical centers}

Eighteen private hospitals participated of the INVITA-ADORI Brazilian Study. The medical centers were located in the cities of Belo Horizonte (2 medical centers), Blumenau (1 medical center), Curitiba ( 1 medical center), Porto Alegre (2 medical centers), São Paulo (7 medical centers), Rio de Janeiro (3 medical centers), Salvador (1 medical center), and São Luís (1 medical center). The selection of the participant medical centers was primarily based on the criteria that they should have $\geq 200$ beds, at least one adult intensive care unit and located in cities with more than one million inhabitants.

\section{Bacterial isolates}

A total of 806 consecutive Gram-negative bacilli were submitted between March 2008 and August 2009. By protocol, each medical center had to submit Gram-negative bacilli collected from patients with diagnosis of pneumonia (20 isolates; 10 of them from ventilated-associated pneumonia), bloodstream infections (20 isolates) and intra-abdominal infections (10 isolates) according to the Centers for Disease Control and Prevention (CDC) definitions. ${ }^{11}$ Just a single isolate per patient was evaluated. All isolates were identified at the participating institution by routine methodologies of each laboratory. Upon receipt at the central laboratory (UNIFESP, São Paulo), isolates were subcultured to ensure viability and purity. Confirmation of species identification was performed with the BD Phoenix $^{\mathrm{TM}}$ Automated Microbiology System (BD Diagnostics, MD, USA) or conventional methods, as required.

\section{Susceptibility testing}

Antimicrobial susceptibility testing was performed by the broth microdilution method, following recommendations of the Clinical and Laboratory Standards Institute (CLSI). ${ }^{12}$ Antimicrobial powders were obtained from the respective manufacturers and microdilution plates were prepared by TREK Diagnostics (West Sussex, England). Susceptibility results were interpreted according to CLSI document M100-S21 for all comparison agents ${ }^{13}$ except for doripenem ${ }^{8}$ and tigecycline. ${ }^{14}$ Quality control was performed by testing E. coli ATCC 25922 and P. aeruginosa ATCC 27853.

\section{RESULTS}

A total of 805 isolates were collected as part of the INVITA-A-DORI Brazilian Study. The bacterial isolates were collected mainly from patients diagnosed with bloodstream $(40.9 \%)$, lower respiratory tract $(39.1 \%)$ and intra-abdominal (15.4\%) infections. The most frequent Gram-negative bacilli collected were P. aeruginosa (26.6\%); E. coli (18.9\%); Klebsiella spp. (18.3\%); Acinetobacter spp. (13.9\%); Enterobacter spp. (8.7\%); and Serratia spp. (6.3\%). They accounted for $92.7 \%$ of the total number of isolates collected as shown in Table 1.

The antimicrobial susceptibility profile of the most frequent Enterobacteriaceae isolates is shown in Table 2. Doripenem $\left(\mathrm{MIC}_{50}, \leq 0.12 \mu \mathrm{g} / \mathrm{mL} ; 97.4 \%\right.$ susceptible) was as potent as meropenem $\left(\mathrm{MIC}_{50}, \leq 0.12 \mu \mathrm{g} / \mathrm{mL}\right.$; 98.0\% susceptible) and at least two-fold more potent than imipenem $\left(\mathrm{MIC}_{50}, 0.25 \mu \mathrm{g} / \mathrm{mL}\right.$; $94.7 \%$ susceptible) against E. coli. Amikacin $\left(\mathrm{MIC}_{50}, \leq 4 \mu \mathrm{g} / \mathrm{mL} ; 97.4 \%\right.$ susceptible), tigecycline $\left(\mathrm{MIC}_{50}, 0.5 \mu \mathrm{g} / \mathrm{mL} ; 97.4 \%\right.$ susceptible), and polymyxin $\mathrm{B}\left(\mathrm{MIC}_{50}, \leq 0.5 \mu \mathrm{g} / \mathrm{mL} ; 96.7 \%\right.$ susceptible $)$ also showed good in vitro activity against $E$. coli. Doripenem $\left(\mathrm{MIC}_{50}, \leq 0.12 \mu \mathrm{g} / \mathrm{mL} ; 85.0 \%\right.$ susceptible $)$ and meropenem $\left(\mathrm{MIC}_{50}, \leq 0.12 \mu \mathrm{g} / \mathrm{mL} ; 83.7 \%\right.$ susceptible) were the most active compounds against Klebsiella spp. followed by imipenem $\left(\mathrm{MIC}_{50}, 0.5 \mu \mathrm{g} / \mathrm{mL} ; 78.2 \%\right.$ susceptible), polymyxin $\mathrm{B}\left(\mathrm{MIC}_{50}, \leq 0.5 \mu \mathrm{g} / \mathrm{mL} ; 91.2 \%\right.$ susceptible $)$ and tigecycline $\left(\mathrm{MIC}_{50}, 1 \mu \mathrm{g} / \mathrm{mL} ; 95.2 \%\right.$ susceptible). Ceftazidime ( $\mathrm{MIC}_{50}, 2 \mu \mathrm{g} / \mathrm{mL} ; 53.7 \%$ susceptible) was four- and sixteen-fold more potent than cefepime $\left(\mathrm{MIC}_{50}, 8 \mu \mathrm{g} / \mathrm{mL}\right.$; $51.7 \%$ susceptible) and ceftriaxone ( $\mathrm{MIC}_{50}, 32 \mu \mathrm{g} / \mathrm{mL} ; 39.5 \%$ susceptible) against Klebsiella spp. isolates, respectively. Against the 70 Enterobacter spp. isolates tested, doripenem $\left(\mathrm{MIC}_{50}\right.$, $0.25 \mu \mathrm{g} / \mathrm{mL})$ and meropenem $\left(\mathrm{MIC}_{50}, 0.12 \mu \mathrm{g} / \mathrm{mL}\right)$ were at least eight-fold more potent than imipenem $\left(\mathrm{MIC}_{50}, 2 \mu \mathrm{g} / \mathrm{mL}\right)$ as shown in Table 2 . Although cefepime $\left(\mathrm{MIC}_{50}, 2 \mu \mathrm{g} / \mathrm{mL}\right)$ was four- and eight-fold more potent than ceftazidime $\left(\mathrm{MIC}_{50}\right.$, $8 \mu \mathrm{g} / \mathrm{mL})$ and ceftriaxone $\left(\mathrm{MIC}_{50}, 16 \mu \mathrm{g} / \mathrm{mL}\right)$, respectively, 
Table 1. Distribution of the most frequent pathogens tested by the INVITA-A-DORI Brazilian Study

\begin{tabular}{|c|c|}
\hline Bacterial genus/species & Amount (\%) \\
\hline Pseudomonas spp. ${ }^{a}$ & $214(26.6)$ \\
\hline Escherichia coli & $152(18.9)$ \\
\hline Klebsiella spp. ${ }^{\mathrm{b}}$ & $147(18.3)$ \\
\hline Acinetobacter spp. ${ }^{c}$ & $112(13.9)$ \\
\hline Enterobacter spp. ${ }^{\mathrm{d}}$ & $70(8.7)$ \\
\hline Serratia spp. ${ }^{\mathrm{e}}$ & $51(6.3)$ \\
\hline Proteus spp. ${ }^{\mathrm{f}}$ & $21(2.6)$ \\
\hline Citrobacter spp. ${ }^{\mathrm{g}}$ & $12(1.5)$ \\
\hline Morganella morgannii & $12(1.5)$ \\
\hline Burkholderia cерасеа & $5(0.6)$ \\
\hline Salmonella spp. ${ }^{\mathrm{h}}$ & $5(0.6)$ \\
\hline Alcaligenes xylosoxidans & $1(0.1)$ \\
\hline Delfia acidovorans & $1(0.1)$ \\
\hline Hafnia spp. & $1(0.1)$ \\
\hline Pantoea spp. & $1(0.1)$ \\
\hline Providencia stuartii & $1(0.1)$ \\
\hline Total & $806(100.0)$ \\
\hline
\end{tabular}

a P. aeruginosa (209), P. fluorescens (02), P. putida (01),

P. stutizeri (01), Pseudomonas spp. (01).

${ }^{\mathrm{b}} \mathrm{K}$. pneumoniae (141), K. oxytoca (06).

c Acinetobacter baumannii (103), A. lwoffii (02), Acinetobacter spp. (07).

${ }^{d}$ E. cloacae (45), E. aerogenes (19), Enterobacter spp. (05),

E. amnigenus (01).

e $S$. marcescens (48), Serratia spp. (02), S. liquefaciens (01).

${ }^{\mathrm{f}} P$. mirabilis (20), $P$. vulgaris (01).

${ }^{g}$ C. freundii (05), C. koseri (03), Citrobacter spp. (02),

C. braaki (01), C. amalonaticus (01).

h Salmonella spp. (04), S. enterica (01).

against Enterobacter spp., only $58.6 \%$ of strains were susceptible to this compound. Amikacin inhibited $67.1 \%$ of Enterobacter spp. In contrast, tigecycline $\left(\mathrm{MIC}_{50}, 1 \mu \mathrm{g} / \mathrm{mL}\right)$ showed a reasonable activity against Enterobacter spp. inhibiting $91.4 \%$ of strains at concentrations $\leq 2 \mu \mathrm{g} / \mathrm{mL}$. Doripenem $\left(\mathrm{MIC}_{50 / 90}, 0.25 / 4 \mu \mathrm{g} / \mathrm{mL}\right)$ and meropenem $\left(\mathrm{MIC}_{50 / 90}\right.$, $0.25 / 2 \mu \mathrm{g} / \mathrm{mL}$ ) were also very potent against cefepime non-susceptible Enterobacter spp. and eight-fold more potent than imipenem $\left(\mathrm{MIC}_{50 / 90}, 2 / 8 \mu \mathrm{g} / \mathrm{mL}\right)$. The highest MIC values for doripenem and meropenem against non-susceptible Enterobacter spp. were $8 \mu \mathrm{g} / \mathrm{mL}$ and $\geq 16 \mu \mathrm{g} / \mathrm{mL}$, respectively. Doripenem $\left(\mathrm{MIC}_{50}, 0.25 \mu \mathrm{g} / \mathrm{mL}\right)$ and meropenem $\left(\mathrm{MIC}_{50}\right.$, $0.25 \mu \mathrm{g} / \mathrm{mL}$ ) exhibited a similar potency to that of levofloxacin $\left(\mathrm{MIC}_{50}, \leq 0.5 \mu \mathrm{g} / \mathrm{mL}\right)$ against $S$. marcescens isolates. The highest susceptibility rates were observed for the carbapenems followed by amikacin (76.5\%), tigecycline $(74.5 \%)$, and cefepime $(70.6 \%)$ as shown in Table 2.
P. aeruginosa and Acinetobacter spp. showed high resistance rates to all compounds tested except for polymyxin $\mathrm{B}$ (Table 3). This compound was the most active antimicrobial agent against $P$. aeruginosa $\left(\mathrm{MIC}_{50}, 1 \mu \mathrm{g} / \mathrm{mL} ; 98.6 \%\right.$ susceptible) and Acinetobacter spp. $\left(\mathrm{MIC}_{50}, \leq 0.5 \mu \mathrm{g} / \mathrm{mL}\right.$; 98.2\% susceptible). Against $P$. aeruginosa, piperacillin/ tazobactam (57.4\%) showed the second highest susceptibility rate. Doripenem and meropenem were equally potent against Acinetobacter spp. $\left(\mathrm{MIC}_{50},>8 \mu \mathrm{g} / \mathrm{mL}\right)$ and P. aeruginosa $\left(\mathrm{MIC}_{50}, 8 \mu \mathrm{g} / \mathrm{mL}\right)$; however, doripenem inhibited a greater number of $P$. aeruginosa isolates (47.3\%) at $\mathrm{MIC}$ values $\leq 4 \mu \mathrm{g} / \mathrm{mL}$ than did meropenem $(39.1 \%)$ or imipenem (38.6\%; Table 4). Doripenem $\left(\mathrm{MIC}_{50}, 16 \mu \mathrm{g} / \mathrm{mL}\right)$ was more active than meropenem $\left(\mathrm{MIC}_{50},>8 \mu \mathrm{g} / \mathrm{mL}\right)$ against imipenem-resistant $P$. aeruginosa isolates, and inhibited $10.5 \%$ of imipenem-resistant $P$. aeruginosa, while meropenem inhibited none of these strains at MIC values of $4 \mu \mathrm{g} / \mathrm{mL}$ (Table 4). Polymyxin B was the only agent active against $97.8 \%$ imipenem-resistant Acinetobacter spp. $\left(\mathrm{MIC}_{50 / 90}, \leq 0.5 / 1 \mu \mathrm{g} / \mathrm{mL}\right)$ and $99.1 \%$ imipenem-resistant P. aeruginosa $\left(\mathrm{MIC}_{50 / 90}, 1 / 2 \mu \mathrm{g} / \mathrm{mL}\right.$ ). Its potency was slightly affected by the carbapenem-resistant phenotype since $100 \%$ of imipenem-susceptible Acinetobacter spp. and $98.8 \%$ of imipenem-susceptible $P$. aeruginosa were inhibited at polymyxin B concentrations of 1 and $2 \mu \mathrm{g} / \mathrm{mL}$, respectively. Only $1.8 \%$ of Acinetobacter spp. isolates showed polymyxin B MIC results $\geq 4 \mu \mathrm{g} / \mathrm{mL}$ and were classified as resistant by CLSI criteria. Full polymyxin B resistance was not detected among $P$. aeruginosa isolates.

\section{DISCUSSION}

The emergence of antimicrobial resistance represents one of the greatest public health threats. An area of particular concern involves Gram-negative pathogen resistance, where few agents are effective or in late-stage of development. ${ }^{15}$ ESBL-producing Enterobacteriaceae have been established as a major cause of nosocomial-acquired infections. Usually, ESBL-producing Enterobacteriaceae also carry genes encoding mechanisms of resistance to other antimicrobial classes such as quinolones, aminoglycosides, and tetracyclines. ${ }^{15,16}$ Enterobacteriaceae resistant to broad-spectrum cephalosporins due to AmpC derepression have also become more frequent in the nosocomial setting. ${ }^{15}$ In addition, ESBL encoding genes have spread out to other bacterial species than E. coli and Klebsiella spp. and reached the community setting. ${ }^{17,18}$ In this manner, carbapenems have become the drug of choice for treatment of serious ESBL and derepressed AmpC infections. ${ }^{15}$

Doripenem represents an attractive option among the carbapenems since (I) it has potent in vitro activity against many Gram-negative and -positive pathogens; ${ }^{1,4,19,20}$ (II) lower propensity to select for resistance; ${ }^{21-23}$ (III) safe tolerability profile with lower seizure potential than imipenem; ${ }^{4,8,24}$ and 
Table 2. In vitro activity of doripenem in comparison to selected antimicrobial agents tested against the main Enterobacteriaceae pathogens collected by the INVITA-A-DORI Brazilian Study

\begin{tabular}{|c|c|c|c|c|c|}
\hline \multirow{2}{*}{$\begin{array}{l}\text { Organism (no. tested)/ } \\
\text { Antimicrobial agent }\end{array}$} & \multicolumn{3}{|c|}{ MIC $(\mu \mathrm{g} / \mathrm{mL})$} & \multicolumn{2}{|c|}{ \% by categorya } \\
\hline & $50 \%$ & $90 \%$ & Range & Susceptible & Resistant \\
\hline \multicolumn{6}{|l|}{ E. coli (152) } \\
\hline Doripenem & $\leq 0.12$ & 0.25 & $\leq 0.12$ to $>4$ & 97.4 & 1.3 \\
\hline Meropenem & $\leq 0.12$ & 0.25 & $\leq 0.12$ to 8 & 98.0 & 1.4 \\
\hline Imipenem & 0.25 & 1 & $\leq 0.12$ to 8 & 94.7 & 2.7 \\
\hline Piperacillin/tazobactam & 2 & $>64$ & $\leq 2$ to $>64$ & 83.6 & 11.2 \\
\hline Ceftriaxone & $\leq 0.25$ & $>32$ & $\leq 0.25$ to $>32$ & 69.7 & 24.9 \\
\hline Ceftazidime & 0.25 & 16 & $\leq 0.12$ to $>16$ & 82.2 & 13.1 \\
\hline Cefepime & $\leq 0.12$ & $>16$ & $\leq 0.12$ to $>16$ & 83.6 & 14.5 \\
\hline Cefoxitin & $\leq 4$ & $>16$ & $\leq 4$ to $>16$ & 72.4 & 17.1 \\
\hline Aztreonam & $\leq 1$ & $>16$ & $\leq 1$ to $>16$ & 78.9 & 18.4 \\
\hline Levofloxacin & 4 & $>4$ & $\leq 0.5$ to $>4$ & 48.0 & 48.0 \\
\hline Amikacin & $\leq 4$ & 8 & $\leq 4$ to $>32$ & 97.4 & 1.3 \\
\hline Polymyxin B & $\leq 0.5$ & 1 & $\leq 0.5$ to $>4$ & 96.7 & $1.3^{\mathrm{b}}$ \\
\hline Tigecycline & 0.5 & 1 & 0.12 to $>4$ & 97.4 & 0.7 \\
\hline \multicolumn{6}{|l|}{ Klebsiella spp. (147) } \\
\hline Doripenem & $\leq 0.12$ & 4 & $\leq 0.12$ to $>16$ & 85.0 & 1.3 \\
\hline Meropenem & $\leq 0.12$ & 4 & $\leq 0.12$ to $>8$ & 83.7 & 10.9 \\
\hline Imipenem & 0.5 & 4 & $\leq 0.12$ to $>8$ & 78.2 & 10.2 \\
\hline Piperacillin/tazobactam & 8 & 64 & $\leq 2$ to $>64$ & 57.1 & 36.1 \\
\hline Ceftriaxone & 32 & $>32$ & $\leq 0.25$ to $>32$ & 39.5 & 57.8 \\
\hline Ceftazidime & 2 & $>16$ & $\leq 0.12$ to $>16$ & 53.7 & 36.0 \\
\hline Cefepime & 8 & $>16$ & $\leq 0.12$ to $>16$ & 51.7 & 47.6 \\
\hline Cefoxitin & 8 & $>16$ & $\leq 4$ to $>16$ & 52.4 & 29.9 \\
\hline Aztreonam & 8 & $>16$ & $\leq 1$ to $>16$ & 46.9 & 47.0 \\
\hline Levofloxacin & 2 & $>4$ & $\leq 0.5$ to $>4$ & 52.4 & 40.1 \\
\hline Amikacin & $\leq 4$ & 32 & $\leq 4$ to $>32$ & 87.8 & 4.1 \\
\hline Polymyxin B & $\leq 0.5$ & 2 & $\leq 0.5$ to $>4$ & 91.2 & $4.8^{\mathrm{b}}$ \\
\hline Tigecycline & 1 & 2 & 0.12 to 4 & 95.2 & 0.0 \\
\hline \multicolumn{6}{|l|}{ Enterobacter spp. (70) } \\
\hline Doripenem & 0.25 & 1 & $\leq 0.12$ to $>16$ & 90.0 & 5.7 \\
\hline Meropenem & 0.12 & 0.5 & $\leq 0.12$ to $>8$ & 94.3 & 2.8 \\
\hline Imipenem & 2 & 4 & 0.25 to $>8$ & 28.6 & 25.7 \\
\hline Piperacillin/tazobactam & 64 & $>64$ & $\leq 2$ to $>64$ & 42.9 & 38.6 \\
\hline Ceftriaxone & 16 & $>32$ & $\leq 0.25$ to $>32$ & 34.3 & 61.5 \\
\hline Ceftazidime & 8 & $>16$ & $\leq 0.12$ to $>16$ & 47.1 & 50.0 \\
\hline Cefepime & 2 & $>16$ & $\leq 0.12$ to $>16$ & 58.6 & 37.1 \\
\hline Cefoxitin & $>16$ & $>16$ & $\leq 8$ to $>16$ & 1.4 & 92.9 \\
\hline Aztreonam & 16 & $>16$ & $\leq 1$ to $>16$ & 45.7 & 52.9 \\
\hline Levofloxacin & 1 & $>4$ & $\leq 0.5$ to $>4$ & 54.3 & 45.7 \\
\hline Amikacin & $\leq 4$ & $>32$ & $\leq 4$ to $>32$ & 67.1 & 27.1 \\
\hline Polymyxin B & $\leq 0.5$ & $>4$ & $\leq 0.5$ to $>4$ & 77.1 & $20.0^{\mathrm{b}}$ \\
\hline Tigecycline & 1 & 2 & 0.25 to 4 & 91.4 & 0.0 \\
\hline
\end{tabular}


Table 2. In vitro activity of doripenem in comparison to selected antimicrobial agents tested against the main Enterobacteriaceae pathogens collected by the INVITA-A-DORI Brazilian Study (Cont.)

\begin{tabular}{|c|c|c|c|c|c|}
\hline \multirow{2}{*}{$\begin{array}{l}\text { Organism (No. tested)/ } \\
\text { Antimicrobial agent }\end{array}$} & \multicolumn{3}{|c|}{ MIC ( $(\mu \mathrm{g} / \mathrm{mL})$} & \multicolumn{2}{|c|}{$\%$ by category } \\
\hline & $50 \%$ & $90 \%$ & Range & Susceptible & Resistant \\
\hline \multicolumn{6}{|l|}{ Serratia spp. (51) } \\
\hline Doripenem & 0.25 & 8 & $\leq 0.12$ to $>16$ & 78.4 & 15.7 \\
\hline Meropenem & 0.25 & 4 & $\leq 0.12$ to $>8$ & 84.3 & 11.8 \\
\hline Imipenem & 2 & 8 & 0.12 to $>8$ & 47.1 & 11.8 \\
\hline Piperacillin/tazobactam & 16 & $>64$ & $\leq 2$ to $>64$ & 54.2 & 35.3 \\
\hline Ceftriaxone & 32 & $>32$ & $\leq 0.25$ to $>32$ & 45.1 & 52.9 \\
\hline Ceftazidime & 2 & $>16$ & $\leq 0.12$ to $>16$ & 62.7 & 25.5 \\
\hline Cefepime & 4 & $>16$ & $\leq 0.12$ to $>16$ & 72.5 & 23.5 \\
\hline Aztreonam & 2 & $>16$ & $\leq 1$ to $>16$ & 58.8 & 35.3 \\
\hline Levofloxacin & $\leq 0.5$ & $>4$ & $\leq 0.5$ to $>4$ & 68.6 & 25.5 \\
\hline Amikacin & $\leq 4$ & 32 & $\leq 4$ to $>32$ & 76.5 & 9.8 \\
\hline Polymyxin B & $>4$ & $>4$ & 0.5 to $>4$ & 7.8 & $90.2^{\mathrm{b}}$ \\
\hline Tigecycline & 2 & 4 & 0.5 to $>4$ & 74.5 & 9.8 \\
\hline
\end{tabular}

a Breakpoint criteria established by CLSI document M100-S21, except for doripenem and tigecycline, where FDA breakpoints were applied.

b According to breakpoints established by CLSI for P. aeruginosa ( $\leq 2 \mu \mathrm{g} / \mathrm{mL}$ for susceptibility and $\geq 8 \mu \mathrm{g} / \mathrm{mL}$ for resistance).

Table 3. In vitro activity of doripenem in comparison to selected antimicrobial agents tested against non-fermentative Gram-negative pathogens collected by the INVITA-A-DORI Brazilian Study

\begin{tabular}{|c|c|c|c|c|c|}
\hline \multirow{2}{*}{$\begin{array}{l}\text { Organism (No. tested)/ } \\
\text { Antimicrobial agent }\end{array}$} & \multicolumn{3}{|c|}{ MIC $(\mu \mathrm{g} / \mathrm{mL})$} & \multicolumn{2}{|c|}{$\%$ by category ${ }^{a}$} \\
\hline & $50 \%$ & $90 \%$ & Range & Susceptible & Resistant \\
\hline \multicolumn{6}{|l|}{ P. aeruginosa (209) } \\
\hline Doripenem & 8 & $>16$ & $\leq 0.12$ to $>16$ & 39.7 & $-{ }^{\mathrm{b}}$ \\
\hline Meropenem & 8 & $>8$ & $\leq 0.12$ to $>8$ & 40.7 & 44.5 \\
\hline Imipenem & $>8$ & $>8$ & $\leq 0.5$ to $>8$ & 40.2 & 53.1 \\
\hline Piperacillin/tazobactam & 64 & $>64$ & $\leq 2$ to $>64$ & 57.4 & 42.6 \\
\hline Ceftazidime & 16 & $>16$ & $\leq 1$ to $>16$ & 44.5 & 45.5 \\
\hline Cefepime & 16 & $>16$ & $\leq 1$ to $>16$ & 45.0 & 43.5 \\
\hline Aztreonam & $>16$ & $>16$ & $\leq 1$ to $>16$ & 26.8 & 54.5 \\
\hline Levofloxacin & $>4$ & $>4$ & $\leq 0.5$ to $>4$ & 43.1 & 52.2 \\
\hline Polymyxin B & 1 & 2 & $\leq 0.5$ to $>4$ & 98.6 & 0.0 \\
\hline \multicolumn{6}{|l|}{ Acinetobacter spp. (112) } \\
\hline Doripenem & $>16$ & $>16$ & $\leq 0.12$ to $>16$ & 12.5 & $-{ }^{\mathrm{b}}$ \\
\hline Meropenem & $>8$ & $>8$ & $\leq 0.12$ to $>8$ & 15.2 & 82.1 \\
\hline Imipenem & $>8$ & $>8$ & 0.5 to $>8$ & 16.1 & 82.1 \\
\hline Piperacillin/tazobactam & $>64$ & $>64$ & $\leq 2$ to $>64$ & 10.7 & 87.5 \\
\hline Ceftriaxone & $>32$ & $>32$ & $\leq 0.25$ to $>32$ & 6.3 & 87.5 \\
\hline Ceftazidime & $>16$ & $>16$ & $\leq 0.25$ to $>16$ & 15.2 & 83.0 \\
\hline Cefepime & $>16$ & $>16$ & $\leq 0.12$ to $>16$ & 13.4 & 83.0 \\
\hline Levofloxacin & $>4$ & $>4$ & $\leq 0.5$ to $>4$ & 10.7 & 83.9 \\
\hline Polymyxin B & $\leq 0.5$ & 1 & $\leq 0.5$ to $>4$ & 98.2 & 1.8 \\
\hline Tigecycline & 1 & 4 & 0.012 to $>4$ & 86.6 & 3.6 \\
\hline
\end{tabular}

${ }^{a}$ Breakpoint criteria established by CLSI document M100-S21, except for doripenem and tigecycline, where FDA breakpoints were applied.

${ }^{\mathrm{b}}$ Interpretative criteria not established by CLSI or FDA. 
Table 4. Cumulative frequency distributions of doripenem, meropenem and polymyxin B against imipenemresistant Acinetobacter spp. and P. aeruginosa isolated from Brazilian patients (INVITA-A-DORI Brazilian Study)

\begin{tabular}{|c|c|c|c|c|c|c|c|c|c|c|c|c|c|c|c|}
\hline \multirow{3}{*}{$\begin{array}{l}\text { Organism } \\
\text { (no. of isolates) }\end{array}$} & \multicolumn{15}{|c|}{ Cumulative \% inhibited at MIC ( $\mu \mathrm{g} / \mathrm{mL})$} \\
\hline & \multicolumn{6}{|c|}{ Doripenem } & \multicolumn{5}{|c|}{ Meropenem } & \multicolumn{4}{|c|}{ Polymyxin B } \\
\hline & $\leq 1$ & 2 & 4 & 8 & 16 & $>16$ & $\leq 1$ & 2 & 4 & 8 & $>8$ & $\leq 0.5$ & 1 & 2 & $4>4$ \\
\hline \multicolumn{16}{|l|}{$\begin{array}{l}\text { Acinetobacter } \\
\text { spp. (112) }\end{array}$} \\
\hline $\begin{array}{l}\text { Imipenem- } \\
\text { resistant (92) }\end{array}$ & 0.0 & 0.0 & 1.1 & 1.1 & 5.4 & 100.0 & 0.0 & 0.0 & 0.0 & 0.0 & 100.0 & 88.0 & 96.7 & 97.8 & 100.0 \\
\hline $\begin{array}{l}\text { Intermediate } \\
\text { to imipenem (2) }\end{array}$ & 0.0 & 0.0 & 0.0 & 50.0 & 100.0 & & 0.0 & 0.0 & 50.0 & 100.0 & & 50.0 & 50.0 & 100.0 & \\
\hline $\begin{array}{l}\text { Imipenem- } \\
\text { susceptible (18) }\end{array}$ & 77.8 & 94.4 & 100.0 & & & & 83.3 & 88.9 & 88.9 & 100.0 & & 77.8 & 100.0 & & \\
\hline \multicolumn{16}{|l|}{ P. aeruginosa (209) } \\
\hline $\begin{array}{l}\text { Imipenem- } \\
\text { resistant (111) }\end{array}$ & 0.0 & 0.0 & 10.8 & 40.5 & 64.0 & 100.0 & 0.0 & 0.0 & 0.0 & 20.7 & 100.0 & 3.6 & 77.5 & 99.1 & 100.0 \\
\hline $\begin{array}{l}\text { Intermediate } \\
\text { to imipenem (14) }\end{array}$ & 21.4 & 35.7 & 71.4 & 85.7 & 92.9 & 100.0 & 21.4 & 28.6 & 57.1 & 71.4 & 100.0 & 14.3 & 71.4 & 92.9 & 100.0 \\
\hline $\begin{array}{l}\text { Imipenem- } \\
\text { susceptible (84) }\end{array}$ & 73.8 & 92.9 & 96.4 & 98.8 & 100.0 & & 76.2 & 84.5 & 91.7 & 98.8 & 100.0 & 14.3 & 75.0 & 98.8 & 100.0 \\
\hline
\end{tabular}

(IV) extended solution stability at room temperature., ${ }^{4,825}$ Sakyo et al. ${ }^{21}$ have shown that the potency of carbapenems in preventing the growth of the carbapenem-resistant $P$. aeruginosa mutants differed for doripenem, imipenem, and meropenem. Mutants were not selected on agar plates containing $1 / 2$ or $1 / 4$ MIC doripenem at a frequency of greater than $10^{-9}$ per cell per generation, whereas mutants of each $P$. aeruginosa strain were selected on agar containing meropenem or imipenem at frequencies of $10^{-7}$ to $10^{-9}$ per cell per generation. Other resistance selection experiments have reported similar results. ${ }^{26}$ Furthermore, a clinical study evaluating doripenem pre- and post-treatment of urinary tract infections showed that microbiological failures were more frequently associated with the acquisition of a new pathogen than by emergence of resistant isolates. ${ }^{27}$

Although a considerable number of studies have reported the potent in vitro activity of doripenem against Gram-negative pathogens, scarce studies have reported the activity of this compound against bacterial pathogens isolated from Brazilian hospitals. ${ }^{19}$ Since the susceptibility rates may vary from distinct hospitals located within the same geographic area due to epidemiological factors, we aimed to evaluate the activity of this agent against Gram-negative pathogens isolated from Brazilian private hospitals. Interestingly, the antimicrobial resistance rates observed among Gram-negative bacilli isolates collected from private hospitals were higher than those previously reported by other surveillance studies that evaluated bacterial isolates mostly collected from public/teaching hospitals. ${ }^{10,19}$ It was expected that the resistance rates would have been lower in private institutions since compliance to infection control policies is assumed to be higher in these institutions than in the public hospitals that sometimes experiment scarcity of resources. The high resistance rates observed in this study could also be partially attributed to the high percentage of Gram-negative pathogens causing nosocomial-acquired bloodstream or lower respiratory tract infections. Our data also reinforce the concept that the level of patient's assistance probably impacts more in the antimicrobial resistance rates than hospital's administrative category, public or private.

The increased $\mathrm{MIC}_{90}$ values for carbapenems against Enterobacteriaceae, especially $K$. pneumoniae, noted in this study might be related to the sporadic occurrence of metallo-betalactamase or mainly KPC (Klebsiella pneumoniae carbapenemase) producers, which has been described in some Brazilian medical centers. ${ }^{28-30}$ P. aeruginosa and Acinetobacter spp. showed high resistance rates to all compounds tested except polymyxin B. Doripenem also demonstrated potent activity against wild type Acinetobacter spp. and P. aerugino$s a$, and was more active than meropenem against imipenemresistant $P$. aeruginosa isolates. Doripenem retained a degree of activity against imipenem- and/or meropenem-resistant $P$. aeruginosa. Specifically, among those $P$. aeruginosa with imipenem MIC values $\geq 8 \mu \mathrm{g} / \mathrm{mL}, 10.8 \%$ were susceptible to 
doripenem at $\leq 4 \mu \mathrm{g} / \mathrm{mL}$ (Table 4 ). Although this categorization is based on a MIC value above the current US-FDA breakpoints, $\mathrm{pK} / \mathrm{pD}$ studies have shown $\mathrm{a} \geq 90 \%$ probability of target attainment for isolates possessing doripenem MICs $\leq 8 \mu \mathrm{g} / \mathrm{mL}$, when higher dosages in prolonged infusion $\left(1 \mathrm{~g}\right.$ tid in 4 -h infusion) were given. ${ }^{31}$ In addition, it has been reported that doripenem prolonged regimens, particularly at the 1-g dose with the 4-h infusion, achieved higher cell kill and resistance suppression rates against wild-type P. aeruginosa. ${ }^{32}$ Since the current US-FDA breakpoints were established based on the licensed dosage (500 mg tid in 1-h infusion), modifications in the doripenem breakpoints for non-fermentative baciili are also expected in the near future. By contrast, doripenem showed little potential against imipenem-resistant Acinetobacter spp. isolates more than $90.5 \%$ showed MIC results at $\geq 8 \mu \mathrm{g} / \mathrm{mL}$.

Doripenem is not hydrolyzed by ESBL and AmpC enzymes; however, like other carbapenems, doripenem remains labile to most carbapenemases. ${ }^{26,33}$ Among carbapenemases, metallo-beta-lactamases (M $\beta \mathrm{Ls}$ ) are considered the most prevalent among non-fermentative bacilli. In Brazilian hospitals, the dissemination of an endemic clone $P$. aeruginosa producer of SPM-1, which is a $\mathrm{M} \beta \mathrm{L}$, has been reported. ${ }^{34}$ In addition, carbapenems are generally hydrolyzed by OXA $\beta$-lactamases commonly reported in Acinetobacter spp. worldwide. ${ }^{35}$ OXA-23-producing isolates have also been reported in Brazilian hospitals. ${ }^{36}$ Although the production of OXA- 23 by itself would not lead to high level resistance to carbapenems, OXA-23-producing isolates may possess other associated mechanisms of resistance since usually they show high resistance to all carbapenems. ${ }^{35,36}$ Thus, the dissemination of SPM-1-producing P. aeruginosa or OXA-23-producing Acinetobacter spp. clones in Brazilian hospitals might justify the low susceptibility rates displayed by carbapenenems observed in this study that figure amongst the lowest ones observed and compared only to the rates of the Asian-Pacific region. ${ }^{37}$

Despite of the limited role of carbapenems for the treatment of non-fermentative infections in Brazilian hospitals, doripenem shows potent in vitro activity compared to that of meropenem. This compound could have its clinical benefit maximized by utilizing higher dosages in prolonged infusion and might exert a lower selective pressure in the hospital microbiota. In addition, doripenem use might have economic and clinical benefit to patients and healthcare delivery. Kollef et al..$^{38}$ assessed medical resource utilization in patients with ventilator-associated pneumonia through a pooled analysis of two prospective, randomized, open-label, multicenter, phase III studies, which also showed that doripenem was clinically non-inferior to comparator agents. The authors observed that in patients with $P$. aeruginosa at baseline, median durations of mechanical ventilation ( 7 versus 13 days; $\mathrm{p}=0.03$ ) and ICU stay ( 13 versus 21 days; $\mathrm{p}=0.02$ ) were shorter for doripenem. Recently, Kongnakorn et al. ${ }^{39}$ using an economic model predicted that doripenem use for treatment of ventilator-associated pneumonia would save an average of approximately $\$ 7,000$ per patient compared to imipenem, with $95 \%$ driven by reduction in hospital length of stay. The model predicted 63\% less seizures, 52\% less emerging P. aeruginosa resistance, and $15 \%$ shorter stays leading to $46 \%$ less transmission associated with doripenem.

As shown in this study, carbapenems may no longer represent an effective drug for empirical treatment of infections caused by non-fermentative and polymyxins represent the last resort drugs for treatment of carbapenem-resistant P. aeruginosa or Acinetobacter spp. infections. However, the emergence of KPC-producing isolates resistant to polymyxins and all clinical available drugs poses a clinical challenge..$^{40}$ Since the high rates of resistance are mainly due to spread of endemic clones, infection control measures must be strictly applied to restore the activity of carbapenems among nonfermentative isolates. At this moment, it is imperative the establishment of task-force groups to oppose this situation at a national level.

\section{ACKNOWLEDGEMENTS}

This study was supported by an educational/research grant from Janssen-Cilag.

\section{REFERENCES}

1. Zhanel GG, Wiebe R, Dilay L, et al. Comparative review of the carbapenems. Drugs. 2007;67(7):1027-52.

2. Tsuji M, Ishii Y, Ohno A, Miyazaki S, Yamaguchi K. In vitro and in vivo antibacterial activities of S-4661, a new carbapenem. Antimicrob Agents Chemother. 1998; 42(1):94-99.

3. Davies TA, Shang W, Bush K, Flamm RK. Affinity of doripenem and comparators to penicillin-binding proteins in Escherichia coli and Pseudomonas aeruginosa. Antimicrob Agents Chemother. 2008;52(4):1510-2.

4. JNJ-38174942 (Doripenem) NDA 22-171: Advisory Committee Briefing Book. Dopipenem for Injection for the Treatment of Nosocomial Pneumonia. 2008; Johnson \& Johnson Pharmaceutical Research \& Development .L.L.C. Meeting of AntiInfective Drugs Advisory Committee.

5. Hanaki H, Kondo N, Inaba $\mathrm{Y}$, Kuwahara K, Asada K. In vitro activity of S-4661, a new 1-beta-methyl carbapenem, against gram-positive and gram-negative bacterial isolates. 1996;36th Intersci. Conf. Antimicrob. Agents Chemother.

6. Sasaki S, Murakami K, Nishitani Y, Kuwahara S. S-4661, a new carbapenem: I. in vitro antibacterial activity. 1994; 34th Intersci. Conf. Antimicrob. Agents Chemother.

7. Cada DJ, Levien T, Mistry B, Baker DE. Doripenem for injection. Hospital Farmacy. 2008; 43(3):210-221.

8. Doribax[package insert]. Raritan, NJ: Ortho-McNeil Pharmaceutical, Inc, 2007.

9. Sader HS, Gales AC. Treatment of severe infections in the era of high rates of antimicrobial resistance. Braz J Infect Dis. 2008;12(Suppl 2):1-2. 
10. Andrade SS, Sader HS, Barth AL, Ribeiro J, Zoccoli C, Pignatari AC, Gales AC. Antimicrobial susceptibility patterns of gram-negative bacilli isolated in Brazilian hospitals participating in the SENTRY Program (2003-2008). Braz J Infect Dis. 2008;12(Suppl 2):3-9.

11. Horan TC, Andrus M, Dudeck, MA. Am J Infect Control. 2008;36:309-332.

12. Clinical and Laboratory Standards Institute (CLSI). M7-A8, Methods for dilution antimicrobial susceptibility tests for bacteria that grow aerobically; approved standard - eighth edition. Wayne, PA: CLSI, 2009.

13. Clinical and Laboratory Standards Institute (CLSI). Performance standards for antimicrobial susceptibility testing: nineteen informational supplement (M100-S21), Wayne, PA: CLSI, 2011.

14. Tygacil [package insert]. Philadelphia, PA: Wyeth Pharmaceuticals Inc, 2005.

15. Paterson DL. Resistance in Gram-negative bacteria: Enterobacteriaceae. Am J Med. 2006; 119: S20-S28.

16. Canton R, Coque TM. The CTX-M $\beta$-lactamase pandemic. Curr Opin Microbiol. 2006;9:466-475.

17. Pitout JD, Nordmann P, Laupland KB, Poirel L. Emergence of Enterobacteriaceae producing extended-spectrum beta-lactamases (ESBLs) in the community. J Antimicrob Chemother. 2005;56:52-59.

18. Minarini LA, Gales AC, Palazzo IC, Darini AL. Prevalence of community-occurring extended spectrum beta-lactamaseproducing Enterobacteriaceae in Brazil. Curr Microbiol. 2007;54:335-41.

19. Gales AC, Jones RN, Sader HS, Fritsche TR. Antimicrobial activity of doripenem tested against leading bacterial pathogens: Results from the Latin American Surveillance Study. Braz J Infect Dis. 2008;12(Suppl2):59-66.

20. Jones RN, Huynh HK, Biedenbach DJ, Fritsche TR, Sader HS Doripenem (S-4661), a novel carbapenem: comparative activity against contemporary pathogens including bactericidal action and preliminary in vitro methods evaluations. J Antimicrob Chemother. 2004;54:144-154.

21. Sakyo S, Tomita H, Tanimoto K, Fujimoto S, Ike Y. Potency of carbapenems for the prevention of carbapenem-resistant mutants of Pseudomonas aeruginosa: the high potency of a new carbapenem doripenem. J Antibiot. 2006;59:220-228.

22. Mushtaq S, Ge Y, Livermore DM. Comparative activities of doripenem versus isolates, mutants, and transconjugants of Enterobacteriaceae and Acinetobacter spp. with characterized $\beta$-lactamases. Antimicrob Agents Chemother. 2004;48:13131319.

23. Huynh HK, Biedenbach DJ, Jones RN, Delayed resistance selection for doripenem when passaging Pseudomonas aeruginosa isolates with doripenem plus an aminoglycoside. Diagn Microbiol Infect Dis. 2006;55:241-243.

24. Redman R, File TM Jr. Safety of intravenous infusion of doripenem. Clin Infect Dis. 2009;49(Suppl 1):S28-35.

25. Psathas PA, Kuzmission A, Ikeda K, Yasuo S. Stability of doripenem in vitro inrepresentative infusion solutions and infusion bags. Clin Ther. 2008;30:2075-2087.

26. Mushtaq S, Ge Y, Livermore DM. Doripenem versus Pseudomonas aeruginosa in vitro: activity against characterized isolates, mutants, and transconjugants and resistance selection potential. Antimicrob Agents Chemother. 2004;48:3086-3092.
27. Davies TA, Shang W, Redman R, Bush K, Flamm B. Genotyping of Gram-negative uropathogens isolated pre- and post-treatment from subjects in a doripenem clinical trial for complicated urinary tract infections, 2008. WPCCID, Taipei, Taiwan.

28. Penteado AP, Castanheira M, Pignatari AC, Guimarães T, Mamizuka EM, Gales AC. Dissemination of $b l a_{\mathrm{IMP}-1}$-carrying integron In86 among Klebsiella pneumonia isolates harboring a new trimethoprim resistance gene $d f r 23$. Diagn Microbiol Infect Dis. 2009;63:87-91.

29. Monteiro J, Santos AF, Asensi MD, Peirano G, Gales AC. First report of KPC-2-producing Klebsiella pneumoniae strains in Brazil. Antimicrob Agents Chemother. 2009;53:333-334.

30. Zavascki AP, Zoccoli CM, Machado AB, et al. KPC-2-producing Klebsiella pneumoniae in Brazil: a widespread threat in waiting? Int J Infect Dis. 2010;14:539-540.

31. Van Wart SA, Andes DR, Ambrose PG, Bhavnani SM. Pharmacokinetic-pharmacodynamic modeling to support doripenem dose regimen optimization for critically ill patients. Diagn Microbiol Infect Dis. 2009;63(4):409-14.

32. Louie A, Bied A, Fregeau C, et al. Impact of different carbapenems and regimens of administration on resistance emergence for three isogenic Pseudomonas aeruginosa strains with differing mechanisms of resistance. Antimicrob Agents Chemother. 2010;54(6):2638-45.

33. Queenan AM, Shang W, Flamm R, Bush K. Hydrolysis and inhibition profiles of beta-lactamases from molecular classes A to D with doripenem, imipenem, and meropenem. Antimicrob Agents Chemother. 2010;54(1):565-9.

34. Gales AC, Menezes LC, Silbert S, Sader HS. Dissemination in distinct Brazilian regions of an epidemic carbapenem-resistant Pseudomonas aeruginosa producing SPM metallo-beta-lactamase. J Antimicrob Chemother. 2003;52(4):699-702.

35. Poirel L, Nordmann P. Carbapenem resistance in Acinetobacter baumannii: mechanisms and epidemiology. Clin Microbiol Infect. 2006;12(9):826-836.

36. Schimith Bier KE, Luiz SO, Scheffer MC, et al. Temporal evolution of carbapenem-resistant Acinetobacter baumannii in Curitiba, southern Brazil. Am J Infect Control. 2010;38(4):308-14.

37. Castanheira M, Jones RN, Livermore DM. Antimicrobial activities of doripenem and other carbapenems against Pseudomonas aeruginosa, other nonfermentative bacilli, and Aeromonas spp. Diagn Microbiol Infect Dis. 2009;63(4):426-33.

38. Kollef MH, Nathwani D, Merchant S, Gast C, Quintana A, Ketter N. Medical resource utilization among patients with ventilator-associated pneumonia: pooled analysis of randomized studies of doripenem versus comparators. Crit Care. 2010;14(3):R84.

39. Kongnakorn T, Mwamburi M, Merchant S, Akhras K, Caro JJ, Nathwani D. Economic evaluation of doripenem for the treatment of nosocomial pneumonia in the US: discrete event simulation. Curr Med Res Opin. 2010;26:17-24.

40. Tóth A, Damjanova I, Puskás E, et al.. Emergence of a colistinresistant KPC-2-producing Klebsiella pneumoniae ST258 clone in Hungary. Eur J Clin Microbiol Infect Dis. 2010;29(7):765-9. 